\title{
FAKTOR-FAKTOR YANG MENGHAMBAT PRIA DEWASA BERHENTI MEROKOK DI RW 06 DESA SIDOPEKSO - KRAKSAAN - PROBOLINGGO
}

\author{
Alwin Widhiyanto \\ Program Studi Sarjana Keperawatan, STIKES Hafshawaty Pesantren Zainul Hasan \\ email: widhiyanto.alwin@gmail.com
}

\begin{abstract}
Abstrak
Merokok merupakan satu dari beberapa masalah yang bisa menghambat tercapainya tujuan pembangunan kesehatan. The Tobacco Atlas 6th Edition (2015), menyebutkan bahwa Indonesia merupakan negara dengan perokok terbesar keempat di dunia. Banyak perokok mencoba berhenti merokok namun sebagian besar kambuh pada minggu pertama. Tujuan penelitian yaitu menganalisis factor-faktor serta mengidentifikasi factor dominan yang menghambat pria dewasa berhenti merokok. Factor tersebut yaitu factor kecanduan, niat, lingkungan, keluarga dan teman. Manfaat penelitian ini untuk mengetahui factor yang menghambat pria dewasa berhenti merokok. Metode penelitian yaitu kuantitatif yang bersifat cross sectional. Populasinya seluruh pria dewasa di RW 06 Desa Sidopekso-Kraksaan-Probolinggo berjumlah 57 orang menggunakan sampling Insidental. Instrumentnya berupa pertanyaan tertutup. Hasil Penelitian didapatkan faktor kecanduan memiliki p value 0,002, faktor niat 0,000 dan faktor lingkungan 0,011 dengan $\alpha$ taraf signifikan 0,05 yang artinya ketiga faktor tersebut menghambat pria dewasa berhenti merokok. Untuk faktor keluarga p value sebesar 0,111 dan faktor teman 0,325 dengan a taraf signifikan 0,05 yang artinya kedua faktor tersebut tidak menghambat pria dewasa berhenti merokok. Faktor niat merupakan faktor yang dominan menghambat pria dewasa berhenti merokok. Upaya yang bisa dilakukan untuk mengurangi atau menghilangkan kebiasaan merokok antara lain: memberi motivasi kepada para perokok untuk berhenti merokok, dan tidak menyediakan rokok dalam setiap kegiatan kemasyarakatan.
\end{abstract}

Kata kunci : merokok, pria dewasa, kecanduan, niat dan lingkungan.

\begin{abstract}
Smoking is one few problems that can obstruct achievement of health development goals. Tobacco Atlas 6th Edition (2015), mentioned that Indonesia is country with fourth largest number of smoker in the world. Many smokers tried to quit smoking, but most smokers relapse. The purposeof this study is to analyze the factors and identify dominant factors inhibit adult men stop smoking. These factors are addiction factor, intention, environmental, family and friend. The benefit of this study is to know the factors that prevent adolescents from smoking. The method used was a quantitative with cross sectional in nature. The population was all men in RW 06 Sidopekso-Kraksaan-Probolinggo of 57 people used incidental sampling. The instrument used questionnaire with closed questions. The results of this study indicated that addiction factor $p$ value is 0.002, intention factor is 0,000 and environmental is 0.011 with significant level of 0.05 so which means these three factors obstructed men to quit smoking. Otherwise, family factor $p$ value is 0.111 and friends factor is 0.325 with significance level 0.05 so which means these two factors did not obstruct to stop smoking. The intention factor was dominant factor obstructed men smoking. Some efforts that can be done to reduce smoking habits is: encourage the smokers to stop smoking, do not provide any cigarettes in each social activity.
\end{abstract}

Keywords : smoking, adult men, addictions, intention and the environment. 


\section{PENDAHULUAN}

Pembangunan di bidang kesehatan merupakan salah satu dari tujuan nasional. Tercapainya hidup sehat bagi setiap warga negara adalah salah satu komponen kesejahteraan umum supaya dapat menciptakan derajat kesehatan masyarakat yang optimal. Kebiasaan merokok merupakan satu dari beberapa masalah yang bisa menghambat tercapainya tujuan pembangunan kesehatan tersebut. Merokok seolah menjadi kegiatan rutin sebagian besar kaum pria, bahkan sudah menjadi suatu kebutuhan yang tidak dapat ditinggalkan. Penggunaan rokok didominasi oleh orang dewasa, baik golongan ekonomi atas, menengah terlebih golongan ekonomi rendah. Kalangan intelektual, orang berpendidikan, tokoh agama maupun orang biasa sudah banyak yang menjadi pengguna rokok. Kegiatan merokok tidak saja dilakukan di tempat terbuka, bahkan di tempat terbatas yang ironisnya sekalipun sudah terdapat tanda atau tulisan larangan merokok, namun para perokok tidak menghiraukan tanda atau tulisan larangan tersebut (Nadia, 2015).

Kegiatan merokok tidak hanya terdapat pada masyarakat Indonesia, akan tetapi juga masyarakat di dunia. World Health Organization (WHO) mengemukakan bahwa pada tahun 2008 didapatkan data satu miliar orang pengguna produk tembakau di seluruh dunia (Aliansi Pengendalian Tembakau Indonesia, 2013). Survei Ekonomi Indonesia pada tahun 2015 melaporkan bahwa Indonesia merupakan salah satu negara yang masih mengalami pertumbuhan dalam sektor industri. Pertanian tembakau dan industri pengolahan tembakau dinilai dapat meningkatan sektor perindustrian nasional di Indonesia khususnya dalam penggunaan produk tembakau, dalam hal ini adalah rokok (PP RI, 2012). Data dari Kementerian Kesehatan RI (2014), menyatakan bahwa Indonesia merupakan peringkat ke-5 sebagai negara penghasil tembakau.

Prevalensi perokok di Indonesia terus mengalami kenaikan dari tahun ke tahun. Jumlah perokok pria meningkat $14 \%$, sedangkan perokok wanita meningkat sebanyak 2,8\% dari tahun 1995 sampai tahun 2011 (Aliansi Pengendalian Tembakau Indonesia, 2013). Berdasarkan hasil penelitian WHO di Indonesia menyatakan bahwa penggunaan tembakau dalam bentuk rokok yaitu $67 \%$ atau 57,6 juta penduduk laki-laki dan 2,7\% atau 2,3 juta penduduk perempuan. Menurut Riset Nasional Dasar Kesehatan 2013, prevalensi merokok di Indonesia yang berusia 15 tahun ke atas meningkat dari $34,2 \%$ pada tahun 2007 menjadi $34,7 \%$ pada tahun 2010, dan menjadi 36,3\% pada tahun 2013. Data dari GATS tahun 2011 menyebutkan bahwa Indonesia merupakan negara ketiga dengan jumlah perokok tertinggi di dunia setelah Cina dan India dengan prevalensi perokok sebanyak 36,1\% (Aliansi Pengendalian Tembakau Indonesia, 2013), data lain menyebutkan The Tobacco Atlas 6th Edition, menyebutkan bahwa Indonesia merupakan negara dengan jumlah konsumsi rokok terbesar keempat di dunia setelah Cina, Rusia, dan Amerika (Pender et $a l, 2015)$.

Rokok adalah salah satu produk tembakau yang dimaksudkan untuk dibakar dan dihisap dan/atau dihirup asapnya, termasuk rokok kretek, rokok putih, cerutu atau bentuk lainnya. Rokok merupakan salah satu produk industri dan komoditi internasional yang mengandung sekitar 300 bahan kimiawi. Unsur-unsur yang penting antara lain : tar, nikotin, benzovrin, metal-kloride, aseton, amonia, dan karbon monoksida (Rahmadita, 2013). Semua orang tahu bahwa merokok lebih banyak memberi kerugian dibandingkan keuntungan. Rokok memiliki dampak yang merugikan baik dari sisi kesehatan, ekonomi, sosial, dan lingkungan (Kemenkes, 2015).

Dari segi kesehatan, diketahui bahwa sebatang rokok mengandung 4000 jenis zat kimia yang berbahaya bagi tubuh dimana 43 diantaranya bersifat karsinogenik. Komponen utama rokok adalah nikotin yaitu suatu zat berbahaya penyebab kecanduan, tar yang bersifat karsinogenik, dan $\mathrm{CO}$ yang dapat menurunkan kandungan oksigen dalam darah. Rokok juga bisa menyebabkan penyakit seperti jantung koroner, stroke dan kanker (kanker mulut, kanker tenggorokan, kanker ginjal, kanker paru) yang pada akhirnya bisa mengakibatkan kematian (Aditama, 2013). Dari segi ekonomi, biaya konsumsi untuk tembakau di Indonesia yang dikeluarkan sebesar Rp 338,75 triliun pertahun. Jumlah tersebut adalah sekitar 6 kali dari pemasukan cukai rokok yaitu sebesar Rp53,9 triliun (Kemenkes, 2011). Dari segi sosial dan lingkungan, asap rokok bisa menyebabkan udara bersih tercemar sehingga menambah polusi udara yang dapat mengakibatkan masalah kesehatan bagi orang yang tidak merokok (Nadia, 2015).

Meskipun sebagian besar masyarakat mengetahui bahaya merokok, akan tetapi mengurangi atau bahkan meniadakan kebiasaan merokok sangatlah sulit yang salah satu alasannya karena rokok dijual bebas, selain itu lingkungan juga mendukung untuk melakukakan aktivitas merokok (Aliansi Pengendalian Tembakau Indonesia, 2013). Berdasarkan Factsheet Global Youth Tobacco Survey tahun 2014 di Indonesia memaparkan 4 dari 5 orang perokok berkeinginan untuk berhenti merokok. Banyak perokok mungkin menyadari risikonya dan termotivasi untuk berhenti merokok, namun mengalami kesulitan untuk berhenti merokok (Rosita dkk, 2012). Di Inggris dan Amerika Serikat, 40\% 
perokok melaporkan telah melakukan percobaan berhenti merokok, namun $75 \%$ usaha berhenti gagal pada minggu pertama (Abikoye et al, 2013). Data lain menyebutkan, Sebanyak 66,20\% perokok pernah mencoba berhenti merokok tetapi tidak berhasil, sedangkan yang berhasil berhenti merokok disebabkan oleh kesadaran sendiri sebanyak $76 \%$, $16 \%$ karena sakit, dan $8 \%$ berhenti merokok karena tuntutan profesi (Amalia R dkk, 2010).

Terdapat beberapa faktor yang dapat menyebabkan kegagalan seseorang untuk berhenti merokok, yaitu : 1). Kecanduan, mereka yang sudah adiksi akan menambah dosis rokok yang digunakan, perokok tidak lagi hanya menyukai sebagai kebiasaan merokok tetapi sudah menganggapnya sebagai suatu kebutuhan sehari-hari bahkan setiap saat atau setiap waktu (Rohayatun dkk, 2015). 2) Niat, Merriam Stoppard berkata tidak ada yang dapat menghentikan keinginan anda untuk berhenti merokok kecuali diri anda sendiri (Winoto YG dkk, 2018). 3) Lingkungan, Tak dapat dipungkiri bahwa di daerah atau lingkungan kita masih banyak toko-toko yang menjual berbagai macam merk rokok. Para perokok itu mungkin berpendapat mengapa kita dilarang merokok atau dianjurkan untuk berhenti karena merokok dapat membahayakan kesehatan dan menimbulkan berbagai macam penyakit tapi pada kenyataannya tidak ada larangan yang menyatakan toko-toko dilarang menjual rokok atau mengapa pemerintah masih saja membiarkan pabrik-pabrik rokok terus berproduksi (Komalasari dkk, 2010).

Faktor yang dapat menyebabkan kegagalan seseorang untuk berhenti merokok yang ke 4) Keluarga, seorang perokok akan sulit menghentikan kebiasaan merokok apabila berada dalam keluarga perokok atau tidak ada dukungan dari keluarga untuk berupaya mengentikan kebiasaan merokok (Komalasari dkk, 2010). 5) Teman, tidak sedikit perokok yang dalam beberapa hari telah berhasil berhenti merokok akhirnya kembali merokok karena bergaul atau berteman dengan seorang perokok. Mereka merokok lagi mungkin karena malu atau tidak tahan dengan ejekan teman-temannya yang masih merokok atau mereka menganggap merokok adalah salah satu penopang bermasyarakat (Winoto YGdkk, 2018).

Tidak ada obat pasti yang bisa menghilangkan kebiasaan merokok, dengan bantuan orang-orang disekitarnya para perokok bisa meninggalkan kebiasaan buruknya tersebut. Ada beberapa upaya yang bisa dilakukan oleh perokok untuk mengurangi atau bahkan menghilangkan kebiasaan merokok dengan bantuan ahli yaitu dengan cara : mengidentifikasi perokok, memberi motivasi untuk berhenti merokok, selanjutnya memberikan dukungan dengan cara konseling, farmakoterapi, dan follow up secara teratur. Tujuan penelitian ini adalah untuk menganalisis faktor-faktor yang menghambat pria dewasa berhenti merokok.

\section{METODE PENELITIAN}

Penelitian ini menggunakan pendekatan kuantitatif dengan jenis penelitian analitik. Peneliti hanya memberi pertanyaan pada responden tanpa melakukan intervensi atau memberikan perlakuan kepada responden. Berdasarkan waktu penelitian, penelitian ini termasuk penelitian cross sectional. Penelitian ini dilaksanakan di RW 06 Desa Sidopekso Kecamatan Kraksaan Kabupaten Probolinggo pada bulan Agustus 2019.

Populasi dalam penelitian ini adalah seluruh pria dewasa RW 06 Desa Sidopekso Kecamatan Kraksaan Kabupaten Probolinggo yang merokok dengan jumlah 57 Orang. Teknik sampling yang digunakan pada penelitian ini sampling insidental.

Teknik pengumpulan data pada penelitian ini dengan kuesioner. Teknik analisis data dalam penelitian ini dilakukan dengan bantuan program aplikasi komputer SPSS menggunakan analisis statistik Univariat, Bivariat dan Multivariat. Tiap faktor mempunyai 5 pertanyaan, sehingga total terdapat 25 pertanyaan.

Taraf signifikansi yang digunakan dalam penelitian ini adalah 95\% dengan derajat kebebasan $(\mathrm{dk}=1)$ dan nilai kemaknaan $(\alpha=5 \%)$. Kriteria hubungan berdasarkan nilai $p$ value (probabilitas) yang dihasilkan dibandingkan dengan nilai kemaknaan yang dipilih, dengan kriteria yaitu: (1) jika $p$ value $>0,05$ maka Ho diterima, (2) jika $p$ value $<0,05$ maka Ho ditolak (Dahlan S, 2014).

Setelah dilakukan analisis Bivariat, maka akan dilakukan analisis multivariat untuk mencari faktor determinan atau faktor yang paling dominan diantara faktor kecanduan, faktor niat, faktor lingkungan, faktor keluarga dan faktor teman yang menghambat pria dewasa berhenti merokok. Analisis Multivariat yang digunakan dalam penelitian ini adalah $U j i$ Regresi Logistik. Variabel bebas yang akan dimasukkan dalam analisis Multivariat ini adalah variabel yang pada analisis Bivariat mempunyai nilai $\mathrm{p}<0,25$.

\section{HASIL DAN PEMBAHASAN}

\section{Hasil}

Pada bagian ini, peneliti akan menyajikan hasil dan analisis data tentang "Analisis faktor-faktor yang menghambat pria dewasa berhenti merokok di RW 06 Desa Sidopekso Kecamatan Kraksaan Kabupaten Probolinggo". Pengambilan data dilakukan dengan menggunakan lembar kuessioner pada pria dewasa berhenti merokok di RW 06 Desa Sidopekso 
Kecamatan Kraksaan Kabupaten Probolinggo sebanyak 57 responden.

\section{Karakteristik Responden Berdasarkan usia}

Tabel 1. Distribusi Frekuensi Responden Berdasarkan Usia

\begin{tabular}{ccc}
\hline Usia & $\begin{array}{c}\text { Frekuensi } \\
(\mathbf{F})\end{array}$ & $\begin{array}{c}\text { Prosentase } \\
(\boldsymbol{\%})\end{array}$ \\
\hline usia 31-40 tahun & 4 & 7.0 \\
usia 41-50 tahun & 27 & 47.4 \\
usia 50-60 tahun & 20 & 35.1 \\
usia >60 tahun & 6 & 10.5 \\
Total & 57 & 100.0 \\
\hline
\end{tabular}

Berdasarkan tabel 1 diketahui bahwa sebagian besar responden adalah berusia antara 41-50 tahun dengan jumlah 27 responden $(47,4 \%)$.

\section{Karakteristik Responden Berdasarkan Pekerjaan}

Tabel 2. Distribusi Frekuensi Responden Berdasarkan Pekerjaan

\begin{tabular}{lcc}
\hline \multicolumn{1}{c}{ Jenis Pekerjaan } & $\begin{array}{c}\text { Frekuensi } \\
(\mathbf{F})\end{array}$ & $\begin{array}{c}\text { Prosentase } \\
(\boldsymbol{\%})\end{array}$ \\
\hline Wiraswasta & 24 & 42.1 \\
Guru/PNS & 25 & 43.9 \\
Lain - lain & 8 & 14.0 \\
\multicolumn{1}{c}{ Total } & 57 & 100.0 \\
\hline
\end{tabular}

Berdasarkan tabel 2 bahwa sebagian besar responden pekerjaannya adalah Guru/PNS dengan jumlah 25 responden $(43,9 \%)$.

Karakteristik Responden Berdasarkan Lama Merokok

Tabel 3. Distribusi Frekuensi Responden Berdasarkan Lama Merokok

\begin{tabular}{lcc}
\hline Lama Merokok & $\begin{array}{c}\text { Frekuensi } \\
(\mathbf{F})\end{array}$ & $\begin{array}{c}\text { Prosentase } \\
(\boldsymbol{\%})\end{array}$ \\
\hline 1-10 tahun & 8 & 14.0 \\
11-20 tahun & 18 & 31.6 \\
21-30 tahun & 17 & 29.8 \\
31-40 tahun & 6 & 10.5 \\
>40 tahun & 8 & 14.0 \\
$\quad$ Total & 57 & 100.0 \\
\hline
\end{tabular}

Berdasarkan tabel 3 diketahui bahwa sebagian besar responden lama merokok adalah antara 11-20 tahun dengan jumlah 18 responden $(31,6 \%)$.
Karakteristik Responden Berdasarkan Kecanduan dan Keinginan berhenti merokok

Tabel 4. Distribusi Frekuensi Responden Berdasarkan kecanduan dan Keinginan berhenti merokok

\begin{tabular}{ccc|c}
\hline \multirow{2}{*}{$\begin{array}{c}\text { Kecanduan } \\
\text { Merokok }\end{array}$} & \multicolumn{2}{c|}{$\begin{array}{c}\text { Keinginan Berhenti } \\
\text { Merokok }\end{array}$} & \multirow{2}{*}{ Total } \\
\cline { 2 - 3 } & $\begin{array}{c}\text { Ingin } \\
\text { Berhenti }\end{array}$ & $\begin{array}{c}\text { Tidak Ingin } \\
\text { Berhenti }\end{array}$ & \\
\hline Kecanduan & 21 & 14 & 35 \\
Tidak kecanduan & 4 & 18 & 22 \\
\hline \multicolumn{1}{c}{ Total } & 25 & 32 & 57 \\
\hline
\end{tabular}

Berdasarkan tabel 4 didapatkan data bahwa responden yang kecanduan merokok berjumlah 35 responden, 21 responden ingin berhenti merokok dan 14 responden tidak ingin berhenti merokok. Responden yang tidak kecanduan merokok berjumlah 22 responden, 4 responden ingin berhenti merokok dan 18 responden tidak ingin berhenti merokok.

Karakteristik Responden Berdasarkan Niat dan Keinginan berhenti merokok

Tabel 5. Distribusi Frekuensi Responden Berdasarkan Niat dan Keinginan berhenti merokok

\begin{tabular}{lc|c|c}
\hline \multirow{2}{*}{ Niat Perokok } & \multicolumn{2}{c}{$\begin{array}{c}\text { Keinginan Berhenti } \\
\text { Merokok }\end{array}$} & \multirow{2}{*}{ Total } \\
\cline { 2 - 3 } & $\begin{array}{c}\text { Ingin } \\
\text { Berhenti }\end{array}$ & $\begin{array}{c}\text { Tidak Ingin } \\
\text { Berhenti }\end{array}$ & \\
\hline Niat & 19 & 6 & 25 \\
Tidak niat & 6 & 26 & 32 \\
\hline \multicolumn{1}{c}{ Total } & 25 & 32 & 57 \\
\hline
\end{tabular}

Berdasarkan tabel 5 didapatkan data bahwa responden yang berniat berhenti merokok berjumlah 25 responden, 19 responden ingin berhenti merokok dan 6 responden tidak ingin berhenti merokok. Responden yang tidak berniat berhenti merokok berjumlah 32 responden, 6 responden ingin berhenti merokok dan 26 responden tidak ingin berhenti merokok.

\section{Karakteristik Responden Berdasarkan Lingkungan dan Keinginan berhenti merokok}

Tabel 6. Distribusi Frekuensi Responden Berdasarkan Lingkungan dan Keinginan berhenti merokok

\begin{tabular}{cccc}
\hline \multirow{2}{*}{$\begin{array}{c}\text { Lingkungan } \\
\text { Perokok }\end{array}$} & \multicolumn{2}{c}{$\begin{array}{c}\text { Keinginan Berhenti } \\
\text { Merokok }\end{array}$} & Total \\
\cline { 2 - 3 } & $\begin{array}{c}\text { Ingin } \\
\text { Berhenti }\end{array}$ & $\begin{array}{c}\text { Tidak Ingin } \\
\text { Berhenti }\end{array}$ & \\
\hline Mendukung & 20 & 15 & 35 \\
Tidak mendukung & 5 & 17 & 22 \\
Total & 25 & 32 & 57 \\
\hline
\end{tabular}


Berdasarkan tabel 6 didapatkan data bahwa lingkungan yang mendukung untuk menghambat berhenti merokok berjumlah 35 responden, 20 responden ingin berhenti merokok dan 15 responden tidak ingin berhenti merokok. Lingkungan yang tidak mendukung dalam menghambat berhenti merokok berjumlah 22 responden, 5 responden ingin berhenti merokok dan 17 responden tidak ingin berhenti merokok.

\section{Karakteristik Responden Berdasarkan Keluarga dan Keinginan berhenti merokok}

Tabel 7. Distribusi Frekuensi Responden Berdasarkan Keluarga dan Keinginan berhenti merokok

\begin{tabular}{lccc}
\hline \multirow{2}{*}{ Keluarga Perokok } & \multicolumn{2}{c}{$\begin{array}{c}\text { Keinginan Berhenti } \\
\text { Merokok }\end{array}$} & Total \\
\cline { 2 - 3 } & $\begin{array}{c}\text { Ingin } \\
\text { Berhenti }\end{array}$ & $\begin{array}{c}\text { Tidak Ingin } \\
\text { Berhenti }\end{array}$ & \\
\hline Mendukung & 8 & 17 & 25 \\
Tidak mendukung & 17 & 15 & 32 \\
Total & 25 & 32 & 57 \\
\hline
\end{tabular}

Berdasarkan tabel 7 didapatkan data bahwa keluarga yang mendukung untuk menghambat berhenti merokok berjumlah 25 responden, 8 responden ingin berhenti merokok dan 17 responden tidak ingin berhenti merokok. Keluarga yang tidak mendukung dalam menghambat berhenti merokok berjumlah 32 responden, 17 responden ingin berhenti merokok dan 15 responden tidak ingin berhenti merokok.

Karakteristik Responden Berdasarkan Teman dan Keinginan berhenti merokok

Tabel 8. Distribusi Frekuensi Responden Berdasarkan Teman dan Keinginan berhenti merokok

\begin{tabular}{lccc}
\hline \multirow{2}{*}{ Teman Perokok } & \multicolumn{2}{c}{ Keinginan Berhenti } & \\
& \multicolumn{2}{c}{ Merokok } & \multirow{2}{*}{ Total } \\
\cline { 2 - 3 } & Berhin & Tidak Ingin & \\
Berhenti & \\
\hline Mendukung & 10 & 17 & 27 \\
Tidak mendukung & 15 & 15 & 30 \\
Total & 25 & 32 & 57 \\
\hline
\end{tabular}

Berdasarkan tabel di atas 8 didapatkan data bahwa teman yang mendukung berhenti merokok berjumlah 27 responden, 10 responden ingin berhenti merokok dan 17 responden tidak ingin berhenti merokok. Teman yang tidak mendukung berhenti merokok berjumlah 30 responden, 15 responden ingin berhenti merokok dan 15 responden tidak ingin berhenti merokok.
Analisis Faktor Kecanduan, Niat, Lingkungan, Keluarga dan Teman dalam menghambat Pria Dewasa Berhenti Merokok

Tabel 9. Distribusi analisis Faktor Kecanduan, Niat, Lingkungan, Keluarga dan Teman dalam menghambat Pria Dewasa Berhenti Merokok

\begin{tabular}{lcl}
\hline \multicolumn{1}{c}{ Variabel } & $\boldsymbol{p}$ value & Keterangan \\
\hline Faktor Kecanduan & 0,002 & H1 diterima \\
Faktor Niat & 0,000 & H1 diterima \\
Faktor Lingkungan & 0,011 & H1 diterima \\
Faktor Keluarga & 0,111 & H1 ditolak \\
Faktor Teman & 0,325 & H1 ditolak \\
\hline
\end{tabular}

Berdasarkan tabel 9 yang dilakukan dengan Uji Chi Square didapatkan data faktor kecanduan pvalue 0,002 , faktor niat pvalue 0,000 dan faktor lingkungan pvalue 0,011 dengan $\alpha$ taraf signifikan 0,05 sehingga dapat disimpulkan $\mathrm{H} 1$ diterima jika harga pvalue < 0,05 yang artinya faktor kecanduan, niat dan lingkungan menghambat pria dewasa berhenti merokok.

Berdasarkan tabel 3.9 yang dilakukan dengan uji Chi Square didapatkan data Faktor Keluarga Pvalue 0,111 dan Faktor Teman Pvalue 0,325 dengan $\alpha$ taraf signifikan 0,05 sehingga dapat disimpulkan $\mathrm{H} 1$ ditolak jika harga $p$ value $<0,05$ yang artinya faktor keluarga dan teman tidak menghambat pria dewasa berhenti merokok.

Faktor Dominan antara Kecanduan, Niat dan Lingkungan yang Menghambat Berhenti Merokok

Tabel 10. Faktor Dominan antara Kecanduan, Niat dan Lingkungan yang Menghambat Berhenti Merokok

\begin{tabular}{lcc}
\hline \multicolumn{1}{c}{ Variabel } & $\boldsymbol{p}$ value & $\operatorname{Exp}(\mathbf{B})$ \\
\hline Faktor Kecanduan & 0,002 & 3,600 \\
Faktor Niat & 0,000 & 9,780 \\
Faktor Lingkungan & 0,011 & 2,139 \\
\hline
\end{tabular}

Berdasarkan tabel di atas faktor yang paling dominan menghambat berhenti merokok adalah niat dengan nilai $\operatorname{Exp}(B)$ 9,780. 


\section{Pembahasan}

\section{Faktor kecanduan}

Hasil penelitian ini menunjukkan data bahwa sebagian besar responden mengalami kecanduan merokok (35 responden). Pada penelitian ini juga didapatkan data bahwa sebagian besar lama merokok responden yaitu 11-20 tahun. Mereka yang sudah adiksi/kecanduan akan menambah dosis rokok yang digunakan bila efek dari rokok yang dihisapnya berkurang. Mereka umumnya juga akan pergi keluar rumah membeli rokok walaupun tengah malam karena khawatir kalau rokok tidak tersedia setiap saat ia menginginkannya (Komalasari dkk, 2010). Orang yang sudah kecanduan akan merasa rnudah lelah, tidak bersemangat dalam melakukan kegiatan, merasa bingung dan gelisah bila tidak merokok dalam satu hari sehingga mereka akan merokok lagi setelah dalam beberapa hari mencoba untuk berhenti merokok yang pada akhirnya akan menghambat orang untuk berhenti merokok.

\section{Faktor Niat}

Hasil penelitian ini, didapatkan data bahwa sebagian besar responden tidak mempunyai niat untuk berhenti merokok (32 responden). Merriam Stoppard menyatakan tidak ada yang dapat menghentikan keinginan anda untuk berhenti merokok kecuali diri anda sendiri (Winoto YG dkk, 2018). Kita terlahir bukan sebagai seorang perokok karena merokok merupakan sesuatu yang dipelajari, sehingga jika seorang perokok tidak mempunyai kemauan/niat untuk berhenti merokok maka hal itu menjadi masalah dalam menghambat seseorang berhenti merokok.

\section{Faktor Lingkungan}

Penelitian ini menunjukkan hasil data bahwa sebagian besar lingkungan responden mendukung untuk menghambat berhenti merokok (35 responden). Sudah kita ketahui bahwa di daerah atau lingkungan kita hampir semua toko menjual berbagai macam merk rokok. Para perokok itu berpendapat mengapa kita dianjurkan untuk berhenti yang pada kenyataannya tidak ada larangan toko menjual rokok dan pemerintah masih saja membiarkan pabrik-pabrik rokok terus berproduksi (Komalasari dkk, 2010). Seseorang akan bersosialisasi dan berinteraksi satu dengan yang lainnya dan merokok sebagai salah satu penopang dalam bermasyrakat. Seorang perokok yang telah berhasil berhenti merokok untuk beberapa hari bisa kambuh lagi karena setiap mengikuti kegiatan desa/kemasyarakatan selalu di sediakan rokok maka hal itu yang bisa menghambat seseorang berhenti merokok.

\section{Faktor Keluarga}

Data yang didapatkan dari hasil penelitian ini bahwa sebagian besar keluarga responden tidak mendukung dalam menghambat berhenti merokok (32 responden), yang artinya keluarga sangat mengharapkan anggota keluarga yang merokok untuk berhenti merokok. Keterikatan keluarga berfungsi sebagai faktor pelindung terhadap berbagai macam perilaku kesehatan yang berisiko termasuk perilaku merokok (Septiana dkk, 2016). Seorang perokok akan sulit menghentikan kebiasaan merokok apabila berada dalam kelurga perokok. Keluarga sebagai bagian terkecil dari masyarakat diharapkan bisa untuk membiasakan hidup bersih dan sehat baik didalam rumah maupun lingkungan sekitar termasuk salah satunya dengan menghentikan kebiasaan merokok.

\section{Faktor Teman}

Hasil penelitian ini menyatakan data bahwa sebagian besar teman responden tidak mendukung dalam menghambat berhenti merokok (30 responden), yang artinya teman sangat mengharapkan responden yang merokok untuk berhenti merokok. Peran teman memang penting dalam kehidupan. Teman dapat memberikan pengaruh positif dapat pula negatif. Pada penelitian ini teman memberikan pengaruh/dukungan yang positif yaitu menganjurkan agar perokok/ responden untuk menghentikan kebiasaan merokok.

\section{Faktor yang Menghambat Berhenti Merokok}

Penelitian ini menunjukkan data bahwa faktor kecanduan, faktor niat dan faktor lingkungan merupakan faktor - faktor yang menghambat pria dewasa untuk berhenti merokok. Mereka yang sudah adiksi akan menambah dosis rokok yang digunakan bila efek rokok yang dihisapnya berkurang. Mereka tidak lagi hanya menyukai sebagai kebiasaan merokok tetapi sudah menganggapnya sebagai suatu kebutuhan seharihari bahkan setiap saat atau setiap waktu (Rahmah L dkk, 2015). Seorang perokok yang sudah kecanduan tidak akan dapat mengurangi jumlah rokok atau bahkan berhenti merokok meskipun sudah mencoba berhenti merokok dengan berbagai cara dan usaha tanpa niat atau kemauan yang keras dari dalam hatinya. Kegiatan lingkungan yang hampir selalu menyediakan rokok dan banyaknya toko yang hampir semua menjual berbagai macam merk rokok akan mempersulit atau menghambat seseorang untuk berhenti merokok. 
Hasil dalam penelitian ini bahwa faktor yang paling dominan dalam menghambat pria dewasa merokok adalah niat. Seorang perokok yang tidak mempunyai kemauan/niat untuk berhenti merokok, maka hal itu akan menjadi masalah terbesar dalam menghambat seseorang berhenti merokok meskipun sudah melakukan berbagai cara untuk mencoba berhenti merokok.

\section{KESIMPULAN DAN SARAN}

\section{Kesimpulan}

Faktor kecanduan, faktor niat dan faktor lingkungan merupakan faktor - faktor yang menghambat pria dewasa untuk berhenti merokok di RW 06 Desa Sidopekso Kecamatan Kraksaan kabupaten Probolinggo.

\section{REFERENSI}

Abikoye, EG, Kashimawo AJ, Eze CU. (2013). Tobacco Smoking and Awareness of Smoking-cessation Products in a University Community. Academic Journal, 5(8), 351-356.

Aditama, T.Y. (2013). Generasi Sehat Generasi tanpa Rokok. Diakses 10 Juli 2019 dari http://www.depkes.go.id. index.php.

Aliansi Pengendalian Tembakau Indonesia. (2013). Peta Jalan Pengendalian Produk Tembakau Indonesia. Surakarta: Muhammadiyah University Press.

Dahlan, Sopiyudin, M., (2014). Statistik Untuk Kedokteran dan Kesehatan. Deskriptif, Bivariat, Multivariat, Dilengkapi Aplikasi Menggunakan SPSS Ed.6. Jakarta: Epidemiologi Indonesia.

Kementerian Kesehatan RI. (2011). Pusat Promosi Kesehatan. Prototipe Media Kawasan tanpa Rokok. Diakses 10 Juli dari www.kemenkes.go.id.

Kementerian Kesehatan RI. (2014). Buku Bunga Rampai Fakta Tembakau dan Permasalahannya di Indonesia. Jakarta Pusat: Tobacco Control Support Centre.

Kementerian Kesehatan RI. (2015). Infodatin Pusat Data dan Informasi Kementerian Kesehatan RI : Perilaku Merokok Masyarakat Indonesia Berdasarkan Riskesdas 2007 dan 2013. Jakarta: Kementerian Kesehatan RI.

Komalasari D dan Helmi AF. (2010). Faktorfaktor Penyebab Perilaku Merokok pada Remaja. Jurnal Psikologi, 27(1), 37-47.
Faktor niat adalah faktor yang paling dominan menghambat pria dewasa berhenti merokok di RW 06 Desa Sidopekso Kecamatan Kraksaan kabupaten Probolinggo.

\section{Saran}

Berbagai upaya disertai niat dan tekad yang kuat untuk mengurangi atau bahkan menghentikan kebiasaan merokok harus dilakukan agar mendapatkan derajat kesehatan yang optimal.

Bagi tempat penelitian dianjurkan untuk tidak menyediakan rokok dalam setiap kegiatan kemasyarakatan (pengajian, kerja bakti, dan lain-lain), setidaknya hal tersebut bisa mengurangi kebiasaan merokok.

Rahmah, L., Sabrian, F. dan Karim, D. (2015). Faktor Pendukung Dan Penghambat Intensi Remaja Berhenti Merokok. JOM, 2 (2), 1195-1204.

Nadia, L. (2015). Pengaruh Negatif Morokok terhadap Kesehatan dan Kesadaran Masyarakat Urban. Tangerang Selatan: Universitas Terbuka. Diakses dari http://repository.ut.ac.id/id/eprint/7088.

Septiana, N., Syahrul dan Hermansyah. (2016). Faktor Keluarga Yang Mempengaruhi Perilaku Merokok Pada Siswa Sekolah Menengah Pertama. Universitas Syiah Kuala. Jurnal Ilmu Keperawatan, 4 (1), $01-14$

Pender NJ, Carolyn LM and Mary Ann. (2015). The Tobacco Atlas Fifth Edition. Diakses 9 Juli $2019 \quad$ dari http://www/tobaccoatlas.org.

Rahmadita. (2013). Peraturan Pemerintah Republik Indonesia No.109 Tahun 2012 tentang Pengamanan Bahan yang mengandung Zat Adiktif berupa Produk Tembakau bagi Kesehatan. Diakses 09 Juli 2019 dari http://sipuu.setkab.go.id/ PUUdoc/173643/PP1092012).

Riset Kesehatan Dasar (Riskesdas). (2013). Jakarta: Kementerian Kesehatan RI.

Rohayatun, Saptiko dan Yanti, SN. (2015). Faktor-faktor yang Mendukung dan Menghambat Perokok untuk Berhenti Merokok di Klinik Berhenti Merokok Puskesmas Kampung Bali Pontianak. Jurnal Cerebellum, 1(4), 266-275. 
Rosita R, Suswardany DL, Abidin Z. (2012). Penentu Keberhasilan Berhenti Merokok pada Mahasiswa Fakultas Ilmu Kesehatan Muhammadiyah Surakarta. Jurnal Kesehatan Masyarakat, 8(1), 1-9.

Salawati, T., Amalia, R. (2010). Perilaku Merokok dikalangan Mahasiswa Universitas Muhammadiyah Semarang. Prosiding Seminar Nasional Universitas
Muhammadiyah. Semarang: LPPM Universitas Muhammadiyah Semarang, 172180.

Winoto, YG., Cahyo, K., Indraswari, R. (2018). Faktor -faktor yang Mempengaruhi Niat Berhenti Merokok pada Siswa Perokok SMP $\mathrm{X}$ di Kota Semarang. Jurnal Kesehatan Masyarakat, 6(5), 814-820. 